Reprod. Nutr. Dévelop., 1980, 20 (3 A), 601-613.

\title{
Digestion of milk protein and methanol-grown bacteria protein in the preruminant calf. I. Kinetics and balance in the terminal small intestine and faecal balance
}

\author{
par P. GUILLOTEAU, R. TOULLEC
}

with the technical assistance of Marguerite BEAUFILS, S. BOUSSION, J. LAREYNIE, Y. MANIS, J. N. NOUCHET

Station de Recherches Zootechniques, I.N.R.A.,

65, rue de Saint-Brieuc, 35042 Rennes Cedex, France.

Summary. The aim of this work was to study the digestion of two milk replacers (control and bacteria), containing different protein sources, in the end of the small intestine and of the digestive tract in the preruminant calf. The protein in the control diet was supplied solely by skim milk powder ; 50.5 p. 100 of the protein of the « bacteria » diet was supplied by methanol-grown bacteria and the rest by skim milk powder and synthetic amino acids (table 1). Five Friesian male calves were fitted with an indwelling cannula in the terminal ileum (table 2) ; 4 other calves were used to measure feed digestibility in the whole digestive tract.

When ileal digesta were not re-entered, transit rate increased slightly (fig. 2) ; however, very moderate changes were observed in the digestive balance in the ferminal ileum (table 4). In our experimental conditions, chromium oxide proved unsatisfactory for carrying out a kinetic study or for correcting the balances in the terminal small intestine (table 5). Nitrogen transit rate seemed slightly higher with the bacteria diet than with the control diet (fig. 2).

The apparent digestibility of both diets was a little lower in the terminal ileum than in the whole digestive tract, except for the fat (tables 3,4). Lipid absorption thus appeared to be finished in the terminal small intestine (table 6). A small part (4 to 5 p. 100) of the apparently digested nitrogen was absorbed in the large intestine, whichever diet was given ; this was also true for the nitrogen-free extract ( 7 and 5 p 100, respectively, for the control and the bacteria diets). A larger part of ash was absorbed in the large intestine (14 and 9 p. 100 , respectively).

The apparent nitrogen digestibility was slightly less for the bacteria diet than for the control one, both in the terminal small intestine (88.8 instead of 91.3 p. 100) and in the faeces (92.8 instead of 95.1 p. 100). Digestibility of bacterial nitrogen was estimated at 86.4 and 90.6 p. 100, respectively, at those two levels. Fat digestibility, on the contrary, was lower for the control diet; this might be explained by the higher saturated fatty acid content of that diet (tables 3, 4).

\section{Introduction.}

Many studies have estimated overall digestive utilization in the preruminant calf (Toullec ef al., 1975). Diet digestion in the abomasum, its transit into the duodenum, and pancreatic secretion have also been thoroughly studied (Roy and Stobo, 1975). Digestion in the small intestine involves many processes, such as transit, endogenous 
secretions, enzymatic hydrolysis and absorption. It is difficult to separate these different aspects; however, it is relatively easy to ascertain their result in the terminal ileum, thus permitting the respective roles of the small and large infestine in nutrient absorption to be defined, and the true composition of some apparently unabsorbed fractions to be determined before they have been considerably changed by the microorganisms. The few studies on this subject in the preruminant calf, have concerned mainly the digestion of either whole milk (Mylrea, 1966a, b; Assan, 1974), milk replacers containing milk (Van Hellemond and Van Weerden, 1973 ; Van Weerden, Huisman and Van Hellemond, 1977) or soya (Sissons and Smith, 1976) proteins, or diets supplemented with starch (Assan, 1974) or sucrose (Chongo-Garcia, 1976).

Using calves fitted with a cannula in the terminal ileum, we have studied the flow and the characteristics of digesta when the protein source of the diet was either milk or methanol-grown bacteria. These observations were completed by measuring the digestive balance in the terminal small intestine. At the same time, we did a methodological study to determine the effect of not re-entering the digesta recovered, and also to ascertain if chromium oxide would be a good solid phase marker. Further, to estimate the part of digestion on either side of the ileocaecal valve, the faecal balances were also measured. These data have already been partially reported by Guilloteau, Toullec and Patureau-Mirand (1979).

TABLE 1

Dief compositions

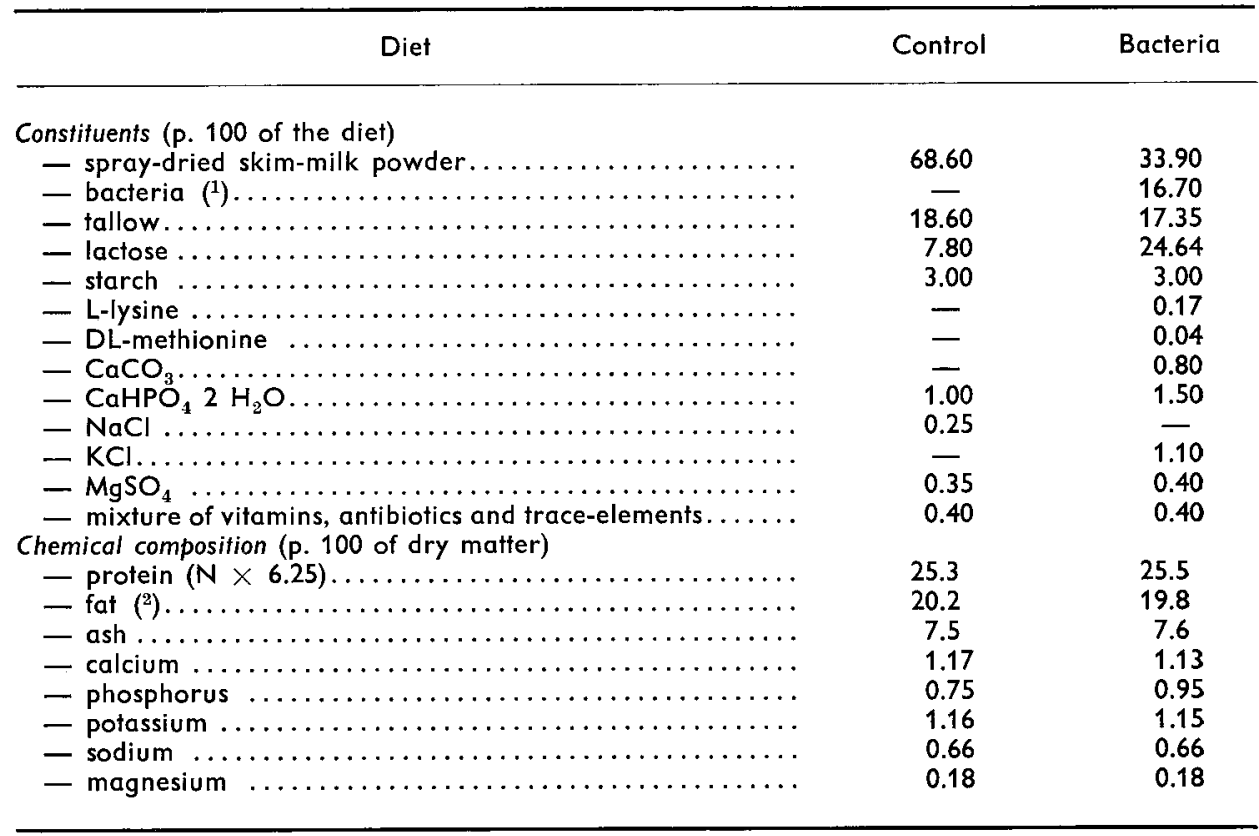

(1) Methanol-grown bacteria containing (p. 100 of DM) 80.4 of protein, 10.5 of fat, 9.6 of ash.

(2) The fats of the control and bacteria diets contained (p. 100 of total methylic esters) :3.0 and 2.4 of myristic acid, 25.4 and 24.3 of palmitic, 2.6 and 5.2 of palmitoleic, 23.1 and 18.5 of stearic, 38.2 and 40.0 of oleic, 2.6 and 4.0 of linoleic and 5.0 and 3.5 of others, respectively. 


\section{Material and methods.}

Diets. - Two milk replacers (control and « bacteria ») were prepared (table 1). The protein in the control diet was furnished exclusively by skim milk powder. 50.5 p. 100 of the protein in the « bacteria » diet was supplied by methanol-grown bacteria (Pseudomonas methylotropha) and the rest by skim milk powder, lysine and methionine.

Animals, feeding and sampling. - Nine Friesian male calves were bought when about 8 days old. Four of them were put into balance crates to measure digestive utilization in the whole digestive tract. The other 5 were fitted with an indwelling cannula in the terminal small intestine to study the digestive kinetics and balance at that level.

Overall digestive utilization. - After they had been present for 32 days, 2 of the calves were fed the control diet and the other 2 the bacteria diet. Four measurement periods were used, the diets being reversed after the first two periods. The first and third periods began 2 weeks after we commenced giving the studied diets. Each period lasted 14 days, during which time the total faeces and urine were collected daily, except on Saturdays and Sundays. The animals were given two meals per day, supplying a total of $60 \mathrm{~g}$ of powder $/ \mathrm{kg}$ of metabolic weight (liveweight ${ }^{\mathbf{0 . 7 5}}$ ).

Feed refusals were weighed after each meal ; they were used to constifute mean samples per calf per period which were stored at $-18^{\circ} \mathrm{C}$ before freeze-drying. Every day, a part of the faeces collected was used to constitute mean samples per calf per period which were treated as the refusal samples. Mean samples per calf per period were taken from an aliquot part of the daily urine; these were stored at $-18{ }^{\circ} \mathrm{C}$ until analysis. The animals were weighed at the beginning and the end of each period.

Digestion in the terminal small intestine. - Two of the fistulated calves were first given the control diet and the other 3 the bacteria diet, the diets being reversed at the end of the 8th week (table 2). Two meals per day were offered, supplying a total of $55 \mathrm{~g}$ of powder per $\mathrm{kg}$ of metabolic weight. When the milk replacers were prepared, chromium oxide was added into the pails at the rate of 0.3 p. 100 of the powder.

TABLE 2

Experimental design used for the fistulated calves

\begin{tabular}{|c|c|c|c|c|c|c|}
\hline Weeks present & 6 & 7 & 8 & 10 & 11 & 12 \\
\hline Calf number & \multicolumn{3}{|c|}{ Control diet } & \multicolumn{3}{|c|}{ Bacteria dief } \\
\hline $\begin{array}{l}26 \\
30\end{array}$ & $\begin{array}{l}\text { Transition, } \\
\text { adaptation }\end{array}$ & $\begin{array}{l}R \\
N R\end{array}$ & $\begin{array}{l}\text { NR } \\
R\end{array}$ & $\begin{array}{l}\text { Transition, } \\
\text { adaptation }\end{array}$ & $\begin{array}{l}R \\
N R\end{array}$ & $\begin{array}{l}\text { NR } \\
R\end{array}$ \\
\hline & \multicolumn{3}{|c|}{ Bacteria diet } & \multicolumn{3}{|c|}{ Control diet } \\
\hline $\begin{array}{l}21 \\
28 \\
29\end{array}$ & $\begin{array}{l}\text { Transition, } \\
\text { adaptation }\end{array}$ & $\frac{R}{D}$ & $\begin{array}{l}\text { NR } \\
\text { NR } \\
R\end{array}$ & $\begin{array}{l}\text { Transition, } \\
\text { adaptation }\end{array}$ & $\begin{array}{l}\text { R } \\
\text { NR } \\
-\end{array}$ & $\begin{array}{l}\text { NR } \\
\text { R } \\
\text { NR }\end{array}$ \\
\hline
\end{tabular}

$R$ : digesta re-entered; NR : digesta not re-entered ; D : digesta discarded because transit seemed abnormal. 
The indwelling cannulae were fitted during the $3 \mathrm{rd}$ and 4 th weeks of presence. The proximal part was fitted to the terminal ileum 5 to $10 \mathrm{~cm}$ before the ileocaecal valve, and the distal part directly into the caecum. Measurements, begun during the 7 th week (the studied diets had been given alone for at least one week before; table 2), were carried out on 4 animals each time. A 5 th calf was used during the 2 nd and 4 th days of sampling because one of the animals fed the bacteria diet had shown an abnormal transit the first day. For each diet, samples were taken on two different days at a one-week interval. During those days, the digesta were totally recovered in melting ice for 24 consecutive hours after the morning meal. Every 2 hrs, they were weighed, homogenized and sampled after the $\mathrm{pH}$ had been measured. Twelve digesta samples (corresponding to 12 2-hour periods) were constituted, as well as a representative 24 -hour mean sample ; these samples were immediately stored at $-18^{\circ} \mathrm{C}$. Samples of the diets and of any refusals were constituted for each sampling day. When there were no refusals, the pails were rinsed to recover the chromium oxide remaining on the sides and the bottom. The mean samples of digesta and of refusals were freeze-dried.

On each sampling day, the digesta not used for analysis were re-entered, by the distal cannula, into one animal per diet after the digesta of a donor calf (given the same diet) had been added. We commenced re-entry about 2 hrs after measurement had started. It was carried out using a peristaltic pump, the mixture being re-heated to about $37^{\circ} \mathrm{C}$ by passage through a heat exchanger. The donor and recipient animals were reversed from one sampling day to the next (table 2).

Analysis. - After freeze-drying the digesta, faeces and food refusals, their dry matter content was determined by drying in an oven at $65 \circ \mathrm{C}$ for $24 \mathrm{hrs}$ and their ash content by ashing at $550^{\circ} \mathrm{C}$. The amount of nitrogen was measured in all the samples using the Kjeldhal method. The dietary and refusal lipids were assayed by Gerber's method and those of the mean digesta and faecal samples by petroleum ether exiraction after warm hydrochloric acid hydrolysis. Diefary fatty acid composition was determined by gas-liquid chromatography of the methylic esters. Chromium oxide was assayed by atomic absorption spectrophotometry after mineralization of the organic compounds.

\section{Results.}

Overall digestive utilization (table 3). - The calves ate all the food offered, except for one animal which refused 19.2 and 14.3 p. 100 of the control and the bacteria diets, respectively. Their growth rate was high with both diets but feed conversion was slightly better with the control diet.

The apparent digestibility was similar for the two diets. However, nitrogen and phosphorus digestibilities were significantly lower with the bacteria diet (2.3 and 4.8 points, respectively). The calculated digestibility of bacterial nitrogen (90.6 p. 100) was 4.5 points lower than that of milk nitrogen. On the other hand, fat digestibility was 6.5 points lower with the control diet. The retention of nitrogen, calcium and phosphorus was similar with both diets. 
TABLE 3

Performances of animals in balance crates and overall digestibility

\begin{tabular}{|c|c|c|}
\hline Diet & Control & Bacteria \\
\hline $\begin{array}{l}\text { Liveweight gain }(\mathrm{g} / \mathrm{d}) \ldots \ldots \ldots \ldots \ldots \ldots \ldots \ldots \ldots \ldots \ldots \ldots \ldots \ldots \ldots \ldots \ldots \\
\text { Dry matter intake } / \mathrm{kg} \text { of liveweight gain }(\mathrm{kg}) \ldots \ldots \ldots \ldots \ldots\end{array}$ & $\begin{array}{l}1188 \\
1.54\end{array}$ & $\begin{array}{r}1167 \\
1.63\end{array}$ \\
\hline 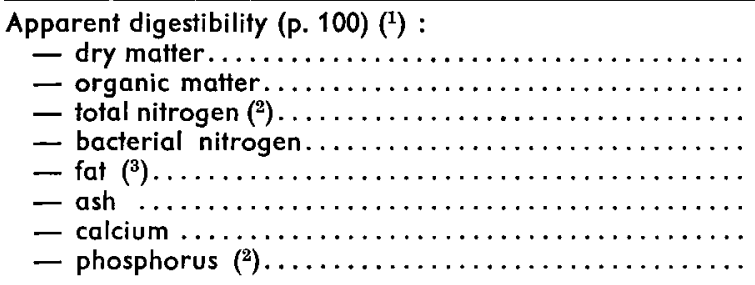 & $\begin{array}{l}94.7(1.1) \\
95.2(1.1) \\
95.1(0.8) \\
- \\
88.3(3.9) \\
88.2(1.6) \\
82.8(2.5) \\
96.3(1.5)\end{array}$ & $\begin{array}{l}95.0(0.6) \\
95.6(0.4) \\
92.8(0.5) \\
90.6 \\
94.8(1.2) \\
88.0(3.3) \\
83.7(5.5) \\
91.5(2.2)\end{array}$ \\
\hline 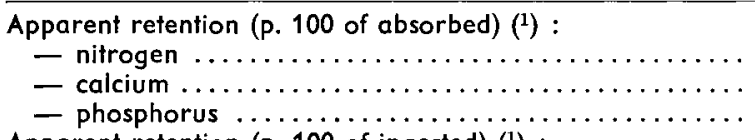 & $\begin{array}{l}53.4(5.6) \\
97.0(0.7) \\
60.5(9.3)\end{array}$ & $\begin{array}{l}55.5(6.7) \\
97.7(0.7) \\
59.5(3.4)\end{array}$ \\
\hline 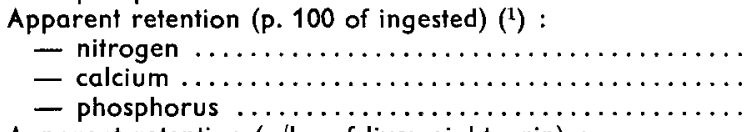 & $\begin{array}{l}50.7(5.1) \\
80.4(2.8) \\
58.3(9.1)\end{array}$ & $\begin{array}{l}51.6(6.2) \\
81.8(5.8) \\
54.5(3.6)\end{array}$ \\
\hline 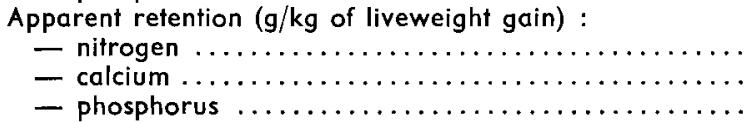 & $\begin{array}{r}31.1 \\
14.4 \\
6.8\end{array}$ & $\begin{array}{r}34.4 \\
15.6 \\
8.4\end{array}$ \\
\hline
\end{tabular}

(1) Mean (sample SD) ; $\left({ }^{2}\right)\left({ }^{3}\right)$ Between-diet differences significant at $P<0.001\left({ }^{2}\right)$ and $0.01\left({ }^{3}\right)$.

TABLE 4

Performances of fistulated calves and digestibility in the terminal ileum

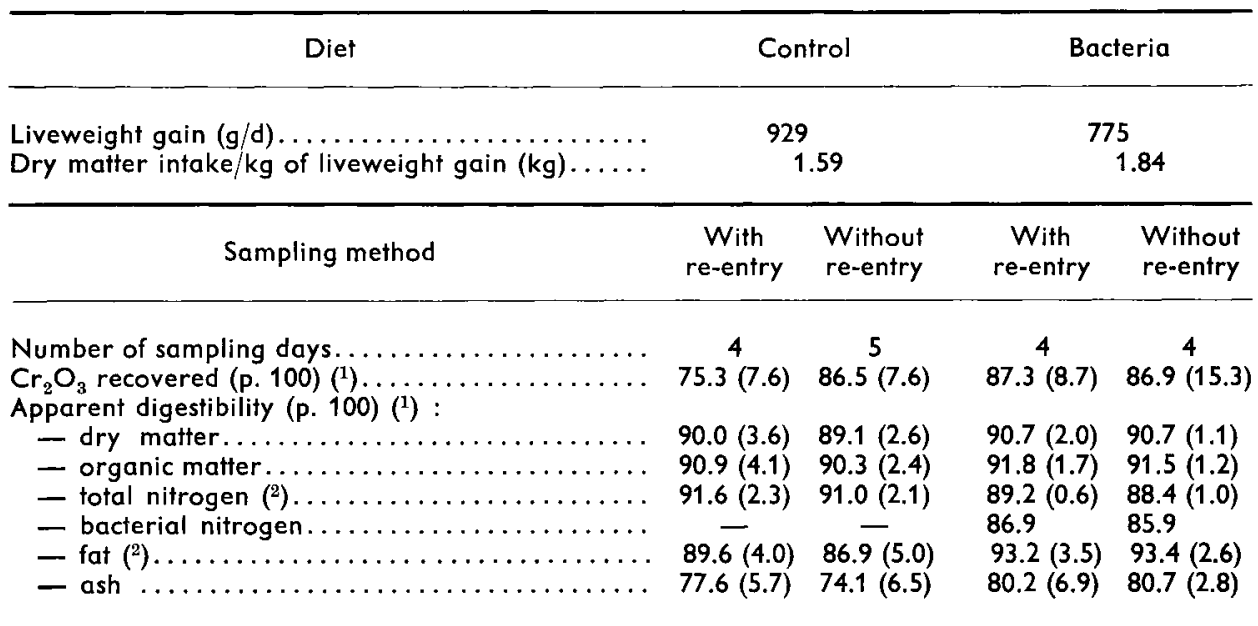

(1) Mean (sample SD); $\left({ }^{2}\right)$ For the whole of the data, the differences between the control and bacteria diets are significant at $P<0.02$. 
Transit and characteristics of digesta in the terminal small intestine. - The growth and the feed conversion of the fistulated calves were less satisfactory (table 4) than that of the animals used for the measurement of overall digestibility. The fistulated calves showed a better performance with the control than with the bacteria diet.

- Digesta composition. Re-entry seemed to have little effect on digesta composition (fig. 1). Dry matter content varied with the diet and the time-course after the meal. It was lower with the control (3.9 to 7.8 p. 100) than with the bacteria (5.1 to 12.6 p. 100) diet. The dry matter content reached two maxima with both diets (one, 8 to $10 \mathrm{hrs}$ after the morning meal and the other, $71 / 2$ to $91 / 2 \mathrm{hrs}$ after the evening meal). Nitrogen content (in p. 100 of the dry matter), reaching two maxima at the mealtimes, was always higher with the bacteria diet.

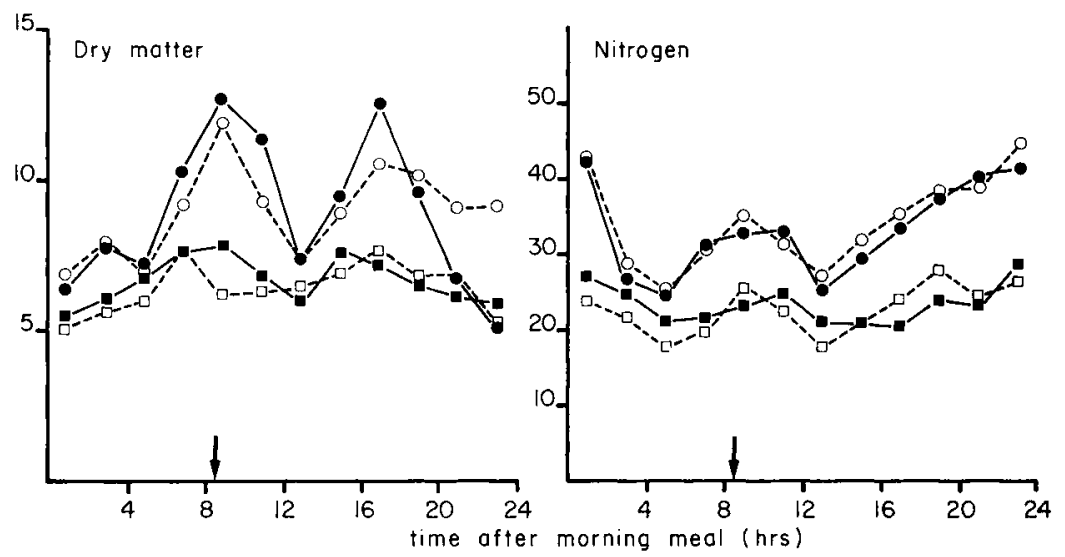

FIG. 1. - Changes in the dry matfer (p. 100 of fresh matter) and the nitrogen (p. 100 of dry matter) contents of digesta. - Control diet, digesta re-entered $(n=-4)$ not re-entered $(n=5) \bullet$ Bacteria diet, digesta re-entered $(n=4)$ - $\ldots$ - Bacteria diet, digesta not re-entered ( $n=4) \downarrow$ Evening meal.

- Kinetic study. With both diets, the hourly flow of the fresh matter, dry matter and nitrogen changed with the time-course after the meal and reached two maxima (fig. 2). When the digesta were re-entered, the first peak appeared sooner with the bacteria diet than with the control one ( 2 to $4 \mathrm{hrs}$ and 4 to $6 \mathrm{hrs}$, respectively), after the morning meal. The second peak, which was higher, appeared at the same time with both diets ( $31 / 2$ to $51 / 2$ hrs after the evening meal). When the digesta were not re-entered, the first peak occured 2 hrs earlier with the control diet, as did the second peak with the bacteria diet.

The flow of fresh material was higher with the control dief than with the bacteria one. On the other hand, the nitrogen content found per 2-hr period was almost always lower with the control diet. There was little difference as to dry matter content.

The hourly flow of chromium oxide showed a very different pattern from that of the fresh matter, dry matter and nitrogen (fig. 2). The correlations were low between 


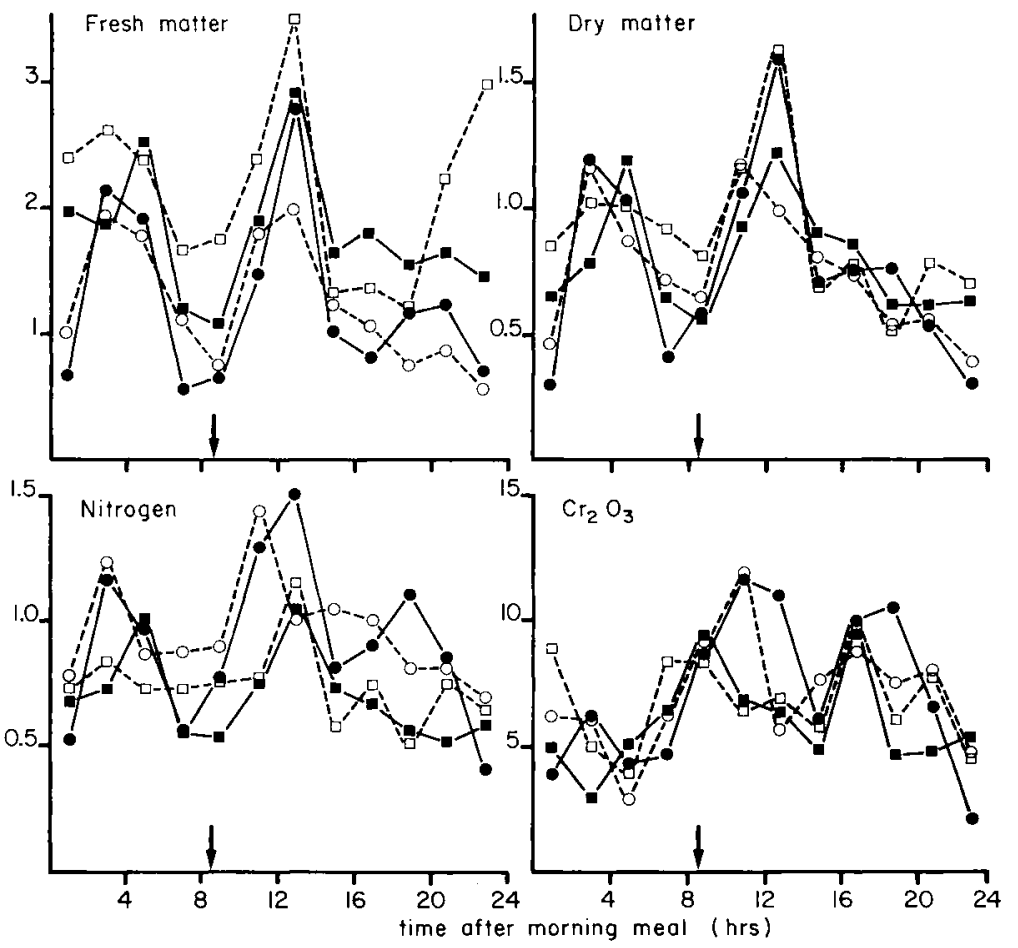

FIG. 2. - Pattern of hourly flow of fresh matter, dry matter, nitrogen and marker (in p. 100 of intake) n- Control diet, digesta re-entered $(n=4) \square-\ldots-\square$ Control diet, digesta not re-entered $(n=5) \bullet-B$ Bacteria diet, digesta re-entered $(n=4) 0-\cdots o$ Bacteria diet, digesta not re-entered $(n=4) \downarrow$ Evening meal.

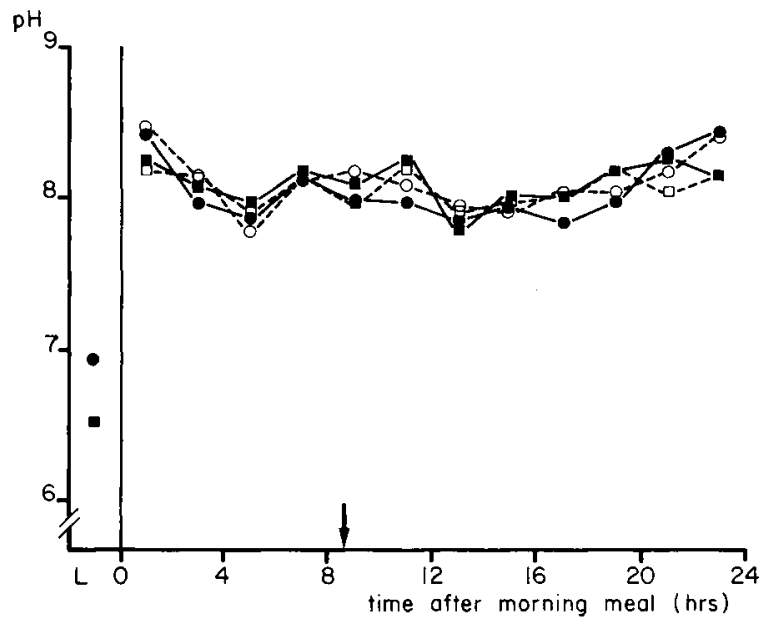

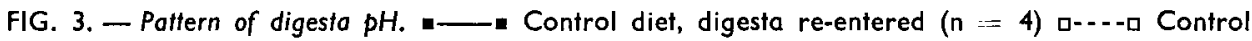
diet, digesta not re-entered $(n=5) \bullet$ Bacteria diet, digesta re-entered $(n=4)$ o $\ldots$ Bacteria diet, digesfa not re-entered $(n=4)$ L Milk replacer $\downarrow$ Evening meal. 
hourly chromium oxide flow, on the one hand, and those of fresh matter, dry matter and nitrogen on the other (table 5). When the data of both sampling methods were grouped, the correlations between the amounts recovered in $24 \mathrm{hrs}$ were also low.

TABLE 5

Correlation coefficients between the marker and the digesta constituents

\begin{tabular}{|c|c|c|c|c|c|c|}
\hline \multirow{2}{*}{ Diet } & \multirow{2}{*}{$\underset{\left({ }^{3}\right)}{\text { Animals }}$} & \multicolumn{5}{|c|}{ Digesta constituents } \\
\hline & & $\begin{array}{l}\text { Fresh } \\
\text { matter }\end{array}$ & $\begin{array}{c}\text { Dry } \\
\text { matter }\end{array}$ & Nitrogen & Fat & $\begin{array}{c}\text { Organic } \\
\text { matter }\end{array}$ \\
\hline \multirow{2}{*}{ Control (1) } & $\mathbf{R}$ & 0.001 & 0.050 & 0.033 & - & - \\
\hline & NR & 0.005 & 0.051 & 0.033 & - & - \\
\hline \multirow{2}{*}{ Bacteria $\left({ }^{1}\right)$} & $R$ & 0.274 & $0.558 * * *$ & $0.679 * * *$ & - & - \\
\hline & NR & 0.001 & 0.046 & $0.350 * *$ & - & - \\
\hline \multirow{2}{*}{ Control $\left({ }^{2}\right)$} & $\mathbf{R}$ & 一 & 0.424 & 0.452 & 0.817 & 0.488 \\
\hline & NR & - & 0.114 & 0.538 & 0.293 & 0.059 \\
\hline \multirow{2}{*}{ Bacteria $\left({ }^{2}\right)$} & $\mathbf{R}$ & - & $0.774 *$ & 0.363 & $0.980 * *$ & 0.823 \\
\hline & $N R$ & - & 0.152 & 0.326 & 0.327 & 0.588 \\
\hline
\end{tabular}

(1) Correlation between the flows per 2-hour periods.

(2) Correlation between the amounts recovered in $24 \mathrm{hrs}$.

(3) R : digesta re-entered ; NR : digesta not re-entered.

${ }^{*}, * *, * * *$ : significant at $P<0.05,0.02$ and 0.01 , respectively.

- pH pattern. In the terminal ileum, the meal seemed to have little effect on digesta $\mathrm{pH}$ (fig. 3). However, the curves showed two minima, one 4 to $6 \mathrm{hrs}$ after the morning meal and the other, $31 / 2$ to $51 / 2 \mathrm{hrs}$ after the evening meal. These minima appeared to coincide with the maxima observed in the flow of fresh matter, dry matter and nitrogen. The $\mathrm{pH}$ differed little according to the diet and the sampling method (with or without re-entry). The values ranged between 7.8 and 8.2 for the control diet and between 7.8 and 8.4 for the bacteria diet.

Digestive balance in the terminal small infestine. - The chromium oxide recovery rate in 24 hrs was about 87 p. 100 with the bacteria diet, whether the digesta were re-entered or not (table 4). It was of the same order (86 p. 100) with the control dief when the digesta were not re-entered, but was lower (75 p. 100) in the opposite case. Consequently, correcting the balances for the control diet by chromium oxide would give slightly lower values for the apparent nitrogen digestibility of dry matter, organic matter and nitrogen $(0.8,0.9,0.8$ points, respectively) in the terminal ileum when the digesta were re-entered than when they were not. It thus seemed preferable not to use these corrections, also taking into account the results of the calculated correlations between chromium oxide flow and those of fresh matter, dry matter and nitrogen. 
The apparent digestibility of the control diet constituents in the terminal ileum was slightly lower when the digesta were not re-entered. The differences were $0.9,0.6$, 0.6, 2.7 and 3.5 points, respectively, for dry matter, organic matter, nitrogen, fat and ash. With the bacteria diet, the differences were even less, except for nitrogen which was 0.8 point. None of these differences being significant, it seemed better in comparing the diets to re-group the results independently of the sampling method.

Apparent nitrogen digestibility was significantly lower with the bacteria diet than with the control one. The mean digestibility calculated for bacterial nitrogen was 86.4 p. 100 instead of 91.3 for milk nitrogen. On the contrary, the other composants studied had a slightly higher digestibility with the bacteria diet; only the difference in the fat was significant, as was the case with the faeces.

\section{Discussion.}

The lower growth of the fistulated calves, as compared to those used for measuring overall digestibility, might be explained by a lower feed intake and the presence of a cannula. However, the cannula caused no digestive disorders or decreased appetite, as described in the pig by Laplace and Borgida (1976) who estimated that fitting the cannula induced an intestino-ileo-caecal reflex closing the sphincter, and a relative atonia of the adjacent intestinal segments. The differences in our study as compared to the latter one could be due to the fact that the digesta were re-entered directly into the caecum, by-passing the ileocaecal valve. Moreover, our feeds were liquid, very digestible and contained no large particles.

When the digesta were not re-entered, the transit was slightly accelerated (especially with the control diet), but not as much as in the sheep duodenum (Hogen and Phillipson, 1962). The changes in the digestive balance in the terminal ileum were very moderate, particularly for dry matter, organic matter, nitrogen and lipids, as Sissons and Smith (1976) also reported. To study the differences in diet digestibility, if thus seemed preferable to use the mean results of both sampling methods.

The correlations between the quantities recovered per period showed that, contrary to the data of Mac Rae ef al. (1972) on sheep, chromium oxide was not a good marker for kinetic studies or for estimating the balances in the terminal small intestine. Since the chromium oxide was not totally recovered, its transit rate might have been reduced by the sampling. When Ehouinsou (1976) took measurements in the sheep duodenum for 3 consecutive days, he noted that chromium oxide and polyethylene glycol transits were strongly reduced during the first 2 days ; quantities of the marker equivalent to quantities ingested were only recovered from the third day. It thus seems difficult to interpret the lower recovery of chromium oxide with the control diet, while there were hardly any differences between the amounts of the digesta constituents recovered. It would seem that the corrected digestibility values were underestimated because there is little chance that re-entry would cause a drop in digestibility. It is thus imperative to choose markers having a fransit closely resembling that of the feed constituents, particularly the nitrogen. It would also be wise to use longer measurement periods.

Contrary to what has been reported in the proximal duodenum (Guilloteau et al., 1975), the meal had litfle effect on digesta flow rate in the ileum, although the flow 
of fresh material augmented slightly 4 to 6 hrs later. These results agree with those obtained by Mylrea (1966a) in the calf fed whole milk. The total amounts of fresh material recovered in $24 \mathrm{hrs}$ in the terminal small intestine were considerable (22 p. 100 of the amount ingested for the control diet), the corresponding values reported by Mylrea (1966) and Johnson and Leibholz (1976) being 18 and 23 to 30 p. 100, respectively, depending on the content and the nature of the dietary lipids.

From our observations, it is difficult to estimate the transit time of the feed constituents. However, the maximal flows of dry matter and nitrogen tended to occur earlier with the bacteria than with the control diet, which agrees with the results of Sissons and Smith (1976) using phenol red and substituting soya products for casein. However, it is certainly risky to relate the flows in the terminal ileum to the transit of feed constituents, considering the important role of endogenous supplies; this would particularly apply to the protein in the control diet since its digestibility was very high.

Faecal apparent nitrogen digestibility with the bacteria diet (90.6 p. 100) was higher than that obtained for any of the substitute proteins we have studied up to now, except for whey and whitefish protein submitted to partial enzymatic hydrolysis (Toullec ef al., 1975). This value agrees with that (90.4 p. 100) reported by Roth and Kirchgessner (1978), and is lower than the one (93.6 p. 100) obtained by Van Weerden and Huisman (1977) for the same product but with a more protein-rich feed (34.4 instead of 25.3 p. 100). Since the true digestibility of milk protein is probably almost total (Roy, Stobo and Gaston, 1970 ; Patureau-Mirand et al., 1977), it is possible to correct the value of 93.6 p. 100 , which would also be about 90 p. 100 with a feed containing 25 p. 100 of protein. The lower digestibility obtained for the fat in the control diet could be due to its higher saturated fatty acid content (table 1) or to a less satisfactory application of its incorporation technology.

Except for the fat, the apparent digestibility of both diets was a liftle lower in the terminal ileum than in the whole digestive tract. This agrees with the bibliographic data (table 6), especially those of Van Weerden, Huisman and Van Hellemond (1977) who used longer measurement periods $(96 \mathrm{hrs}$ ) than we did. Lipid absorption thus seemed to be finished in the terminal small intestine. A small part (4 to 5 p. 100) of the apparently digestible nitrogen was absorbed in the caecum and the colon with both diets, as was the nitrogen-free extract ( 7 and 5 p. 100, respectively, with the control and the bacteria diets), thus confirming that, contrary to some starch products, a large part of which is digested in the large intestine (Assan, 1974), almost all the lactose was cleared in the small intestine (Mylrea, 1966b). The part absorbed in the large intestine was higher for the ash (14 and 9 p. 100, respectively, for the control and the bacteria diets); this is not surprising considering the role of the large intestine in the absorption of magnesium, sodium and chlorine (Smith, 1959, 1962, 1969 ; Perry, Cragle and Miller, 1967).

In conclusion, our results indicate that it is not necessary to re-enter the digesta obtained in the terminal small intestine because the changes in transit and digestive balance are low. Chromium oxide is apparently not suitable for kinetic studies or for correcting balances. Replacing half of the milk protein by that from methanolgrown bacteria had a depressive effect on nitrogen digestibility, which was of the same order in the terminal small intestine as in the faeces. The increase in the quantity 


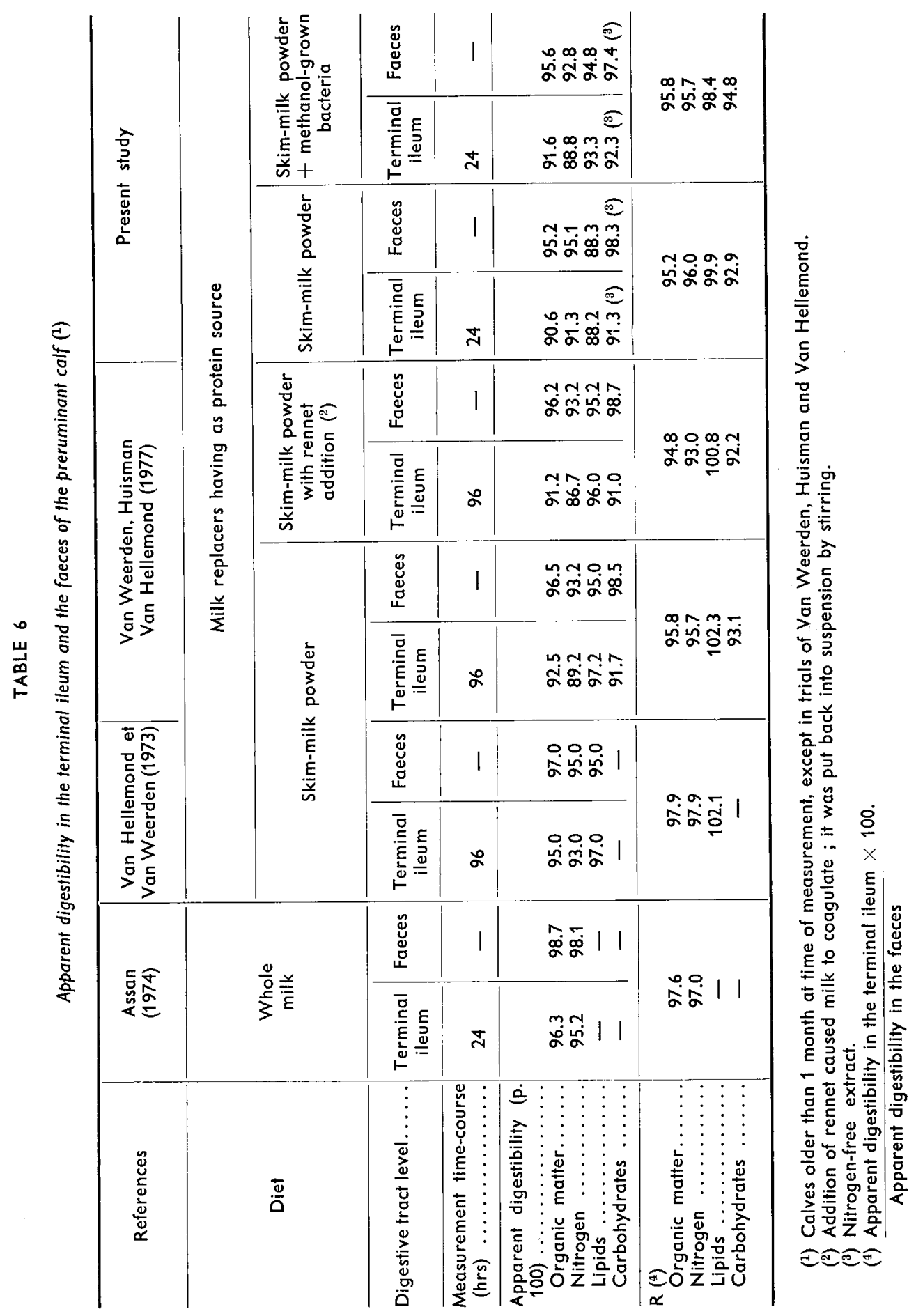


of nitrogen excreted could be of endogenous or dietary origin. The determination of the amino acid composition of the digesta and the faeces, reported in the second part of this study, should permit an evaluation of the respective roles of these two sources.

Reçu en avril 1979.

Accepté en septembre 1979.

Acknowledgements. - We wish to thank the $\mathrm{ICl}$ Company (Agricultural Division, Protein Department, PO Box 1, Billingham, Cleveland TS 231 LB, England) for financial help in carrying out this study and Mr. Brule (Laboratoire de Technologie Laitière, INRA, Rennes) who advised us on the chromium assay.

Résumé. Le but de ce travail était d'étudier la digestion de 2 laits de remplacement (Témoin et Bactéries) différant par l'origine de leurs matières azotées, à la fin de l'intestin grêle et du tube digestif du veau préruminant. Les matières azotées de l'aliment Témoin étaient fournies exclusivement par la poudre de lait écrémé ; 50,5 p. 100 de celles de l'aliment Bactéries étaient apportées par des bactéries cultivées sur méthanol ef le reste par la poudre de lait écrémé et des acides aminés de synthèse (tabl. 1). Cinq veaux mâles de race Frisonne ont été munis d'une canule réentrante à la fin de l'iléon (tabl. 2); 4 autres veaux ont été utilisés pour mesurer la digestibilité des aliments à la fin du tube digestif.

La non-réintroduction des digesta iléaux entraîne une légère accélération du transit (fig. 2) ; cependant, les modifications observées dans le bilan de la digestion à la fin de l'iléon sont très modérées (tabl. 4). Dans nos conditions expérimentales, l'oxyde de chrome n'est satisfaisant ni pour effectuer une étude cinétique, ni pour corriger les bilans à la fin de l'intestin grêle (tabl. 5). Le transit de l'azote semble un peu plus rapide avec l'aliment Bactéries qu'avec l'aliment Témoin (fig. 2).

La digestibilité apparente des 2 aliments est un peu moins élevée à la fin de l'iléon que dans l'ensemble du tube digestif, sauf pour les matières grasses (tabl. 3 ef 4). L'absorption des lipides paraît donc quasiment achevée à la fin de l'intestin grêle (tabl. 6). Une faible part (4 à 5 p. 100) de l'azote apparemment digestible est absorbée par le gros intestin quel que soit l'aliment. II en est de même pour l'extractif non azoté (7 et 5 p. 100 respectivement pour les aliments Témoin ef Bactéries). La part absorbée dans le gros intestin est plus importante pour les matières minérales (respectivement 14 et 9 p. 100).

La digestibilité apparente de l'azote est un peu moins élevée pour l'aliment Bactéries que pour l'aliment Témoin, à la fois à la fin de l'intestin grêle $(88,8$ p. 100 au lieu de 91,3) et au niveau des fèces $(92,8$ p. 100 au lieu de 95,1). La digestibilité de l'azote des bactéries peut être estimée à 86,4 et à 90,6 p. 100 respectivement à ces 2 niveaux. La digestibilité des matières grasses est au contraire moins élevée pour l'aliment Témoin, ce qui peut s'expliquer par leur teneur plus forte en acides gras saturés dans cet aliment (tabl. 3 et 4).

\section{References}

ASSAN E. B., 1974. Contribution d̀ l'étude de la digestion intestinale de l'amidon chez le veau préruminant. Th. Doct.-Ingén., Univ. Clermont-Ferrand, sér. I, $n^{0} 64$.

BLAXTER K. L., WOOD W. A., 1953. Some observations on the biochemical and physiological events associated with diarrhoea in calves. Vet. Rec., 50, 889-892.

CHONGO-GARCIA B. M., 1976. Efude de la digestion infestinale de la mélasse de canne à sucre chez le veou préruminant. Th. Doct. Univ., Univ. Clermont-Ferrand, sér. D. U., $n^{0} 52$.

EHOUINSOU M. A., 1976. Efude de la digestion du lactose chez le mouton. Th. Doct.-Ingén., Univ. Clermont-Ferrand, sér. D. I., $n^{0} 77$.

GUILLOTEAU P., PARUELLE J.-L., TOULLEC R., MATHIEU C.-M., 1975. Utilisation des protéines par le veau préruminant à l'engrais. III. Influence du remplacement des protéines du lait par celles du poisson sur la vidange stomacale. Ann. Zootech., 24, 243-253. 
GUILLOTEAU P., TOULLEC R., PATUREAU-MIRAND P., 1979. Bilan de la digestion des matières azotées du lait et des bactéries cultivées sur méthanol à la fin de l'intestin grêle et du fube digestif du veau préruminant. Ann. Biol. anim. Bioch. Biophys., 19, 949-953.

HOGAN J. P., PHILLIPSON A. T., 1962. The rate of flow of digesta and their removal along the digestive tract of the sheep. Brit. J. Nutr., 14, 147-155.

JOHNSON R. J., LEIBHOLZ J., 1976. The effect of fat source on abomasal and ileal flow in the preruminant calf. Proc. oustr. Doc. Anim. Prod., 11, 19 p.

LAPLACE J. P., BORGIDA L. P., 1976. Problèmes physiologiques posés par la fistulation réentrante chronique de l'iléon chez le porc. Ann. Zootech., 25, 361-371.

Mac RAE J. C., ULYATT H. J., PEARCE P. D., HENDTLASS J., 1972. Quantitative infestinal digestion of nitrogen in sheep given formaldehyde-treated and untreated casein supplements. Brit. J. Nutr., 27, 39-50.

MATHIEU C.-M., 1968. Efude de la vidange stomacale du lait entier chez le veau préruminant. Ann. Biol. anim. Bioch. Biophys., 8, 581-583.

MYLREA P. J., 1966a. Digestion of milk in young calves. I. Flow and acidity of the contents of the small intestine. Res. vet. Sci., 7, 333-341.

MYLREA P. J., 1966b. Digestion of milk in young calves. II. The absorption of nutrients from the small intestine. Res. vef. Sci., 7, 394-406.

PATUREAU-MIRAND P., TOULLEC R., GUILLOTEAU P., PION R., 1977. Influence de la nature des protéines alimentaires sur la composition en acides aminés des fèces du veau préruminant. Ann. Biol. anim. Bioch. Biophys., 17, 71-83.

PERRY S. C., CRAGLE R. G., MILLER J. K., 1967. Effect of ration upon the intestinal distribution of $\mathrm{Ca}, \mathrm{Mg}, \mathrm{Na}, \mathrm{K}$ and $\mathrm{N}$ in calves. J. Nuir., 93, 283-290.

ROTH F. X., KIRCHGESSNER M., 1978. Stoffwechselergebnisse von Kälbern bee partiellem Austauch von Milch protein durch Bacteriennasse. Z. Tierphysiol. Tierernährg u Futfermittelkde, 41, 29-39.

ROY J. H. B., STOBO I. J. F., 1975. Nutrition of the preruminant calf. In Mc DONALD J. W., WARNER A. C. I. Digestion and metabolism in the ruminant. Proc. IV th int. Symp. on ruminant physiology, 30-48. Univ. of New England Publ. Unit., Armidale.

ROY J. H. B., STOBO I. J. F., GASTON H. J., 1970. The nutrition of the veal calf. 2. The effect of different levels of protein and fat in milk substitute diets. Brit. J. Nutr., 24, 411-457.

SISSONS J. W., SMITH R. H., 1976. The effect of different diets including those containing soya-bean products, on digesta movement and water and nitrogen absorption in the small intestine of the preruminant calf. Brit. J. Nutr., 36, 421-438.

SMITH R. H., 1959. Absorption of magnesium in the large intestine of the calf. Nature, 184, 811-822.

SMITH R. H., 1962. Net exchange of certain inorganic ions and water in the alimentary tract of the milk-fed calf. Biochem. J., 83, 151-163.

SMITH R. H., 1969. Absorption of major minerals in the small and large intestine of ruminant. Proc. Nutr. Soc., 28, 151-160.

TOULLEC R., PATUREAU-MIRAND P., THIVEND P., VERMOREL M., 1975. Bases physiologiques de la réalisation des aliments d'allaitement pour veaux. Bull. Soc. Sci. Hyg. Alim., 63, 69-100.

TOULLEC R., THIVEND P., MATHIEU C.-M., 1971. Utilisation des protéines du lactosérum par le veau préruminant à l'engrais. I. Vidange stomacale comparée du lait entier et de deux laits de remplacement ne contenant que des protéines de lactosérum comme source de matières azotées. Ann. Biol, anim. Bioch. Biophys., 11, 435-453.

VAN HELLEMOND K. K., VAN WEERDEN E. J., 1973. Milk protein substitutes in rations for veal calves. Proc. Nutr. Soc., 32, 231-235.

VAN WEERDEN E. J., HUISMAN J., 1977. Digestibility of protein and amino acids of a fermentation single cell protein for veal calves. Ann. Fd Sci. Techn., 2, 377-383.

VAN WEERDEN E. J., HUISMAN J., VAN HELLEMOND K. K., 1977. Verteringsfysiologisch onderzoek. Enkele uitkomsten ten aanzien van het verterings proces in het maagdarmkanaal van het mestkalf. Londbouwkundig Tijdschrift, 89, 217-224. 